Institute for Physical Chemistry at Dahlem, who had used the so-called small-angle dispersion in his X-ray work.

Probably the greatest name, on the Continent at least, in macromolecular physics and chemistry is that of Dr. H. Staudinger of Freiburg i. Br., who recently completed his three hundredth paper on the subject. At Weimar, he reviewed his work on cellulose and introduced the results of his latest research on the relation between molecular chain-length and strength of fibre in the polyamide group. He referred also to the viscosity of dilute solutions of,these products, a matter with which he had previously dealt in considerable detail, under the heading of moleculecolloids. Dr. F. H. Müller, of the University of Leipzig, dealt with specific viscosity in relation to structure in solutions; and Dr. Moll, of Berlin, discussed some. differences between ordinary cotton and various artificial Zellwollen, and the effect of spinning methods, degree of polymerization, etc., using density measurements of the greatest accuracy. New methods of measuring these various factors were disclosed by Dr. A. Marschall, of the Zehlendorf textile factory, with special reference to the solubilities of various natural and artificial cellulose products.

Other papers dealt with longitudinal swelling of cellulose and Zellwollen; relation between degree of swelling and textile properties ; treatment of cellulose with formaldehyde and other substances with a view to the introduction into the molecule complex of foreign materials and to so-called bridge-building for controlled modification of properties; and various methods of testing both artificial and natural fibres. No new fibres were introduced, with the exception of a new acetate silk by Dr. A. Sippel, of the Rhodiaseta Works at Freiburg, for which remarkable strength is claimed.

\section{WELFARE OF WAR-WORKERS AND SEAMEN}

A REPORT issued by the Ministry of Labour and National Service on "Welfare Outside the Factory and Seamen's Welfare in Port" (Cmd. 6411) gives some account of the work of the Welfare Department of the Ministry, August 1941-August 1942 (London : H.M. Stationery Oltice, 2d. net).

In regard to the transference of war workers to various parts of Great Britain, a 'convoy' system under which, for example, wamen coming from Scotland to the Midlands meet at Edinburgh or Glasgow and are then brought down in a party overnight in specially reserved compartments, accompanied by officers of the Ministry, and are met at Birmingham by the reception officers, has proved extremely successful. In regard to lodging and billeting, the formation of local advisory committees, including representatives of the local authority, regional officers of the Ministry of Health and Ministry of Labour and National Service, the women's voluntary services and employers and trade unions promises to give good results in difficult areas. Reference is again made to shopping difficulties, to problems of travel to and from work, and to the care of transferred workers during sickness, all of which are receiving attention, as are problems of recreation, entertainment and holidays, while to free mothers for war work, special steps have been taken to see that their children are cared for during working hours.
In regard to seamen's welfare, the provision of hostels has been a major task of the Department, and such hostels have already been provided at Liverpool, Cardiff, Newcastle and Hull, while others are being established at Leith and Glasgow. These Merchant Navy Houses are managed by the National Service Hostels Corporation. Recreational centres with facilities for meals and a drink have been established at Newport and Hull, and others are being established at Swansea and Avonmouth. Health questions are also receiving attention, and the hospitals now make known to the seamen's welfare officer the names of all merchant seamen who have been admitted, to facilitate visiting and the supply of books, periodicals, etc.

\section{FORTHCOMING EVENTS}

(Meeting marked with an asterisk is open to the public.)

Saturday, January 23

Chemercal Societr (in the Chemistry Lecture Theatre, University College, Shakespeare Street, Nottingham), at 3 p.m.-Dr. R. A. Morton : "Vitamin-A".

Monday, January 25

RoYaI Geographical Soctety (at Kensington Gore, London, S.W.7), at 5 p.m.-Mrs. Reginald Wyndham: "Java, Sumatra, Celebes, Flores and Bali" (Kodachrome and other films)

\section{Tuesday, January 26}

RoYal ANThropological INSTITUTE (at 21 Bedford Square, London, W.C.1), at 1.30 p.m.-Dr. M. J. Field: "Some Aspects of Indirect Rule".

ROYA InstituTion (at 21 Albemarle Street, London, W.1), at 3 p.m. Sir Lawrence Bragg, F.R.S.: "The Solid State", (i) "Atomic Architecture":"

\section{Wednesday, January 27}

Royat Socrery of ARTS (at John Adam Street, Adelphi, London, W.C.2), at 1.45 p.m.-Dr. I. S. Russell : "Trawling and the Stocks of Fish".

GEOLOGICAL SOCIETY OF LONDON (at Burlington House, Piccadilly London, W.1), at 3 p.m. -Dr. K. S. Sandford: "The Geology of Northern French Africa".

Saturday, January 30-Sunday, January 31

Assoclation of SOIENTIFTC WORKERS (at Caxton Hall, Westminster, London, S.W.1). Conference on "Planning of Science, in War and in Peace" (to be opened by Sir Robert Watson-Watt, F.R.S.)

\section{APPOINTMENTS VACANT}

Applications are invited for the following appointments on or before the dates mentioned:

Lecturer in Physics and Mathematics at the Croydon Polytechnic - The Education Officer, Education Office, Katharine Street, Croydon (January 29).

IECTURER in EleECrRical ENGINEering at the Oxford Schools of Technology, Art and Commerce-The Chief Education Officer, City Technology, Art and Commerce-The Coief Education

ChAIR of Minivi--The Secretary, The University, Edmund Street, Birmingham, 3 (March 1).

SEnior Physics MASTER-The Headmaster, Ellesmere College, Ellesmere, Shropshire.

Assistant Horticulteral OFFtogr-The Chief Executive Officer, War Agricultural Exccutive Committee, The Deanery, Worcester.

Teacher (Man or woman) of Mathematics, pidus Physics and/OR CHEMISTRY - The Headmaster, The School, Dartington Hail, Totnes, Devon.

Lamoratory Steward for the Sierra Leone Government Medical Department-The Secretary, Overseas Manpower Committee (Ref. 624), Ministry of Labour and National Service, Hanway House, Red Lion Square, London, W.C.1.

\section{REPORTS and other PUBLICATIONS}

\section{(not included in the monthly Books Supplement)}

\section{Great Britain and Ireland}

UFAW : the Universities Federation for Animal Welfare. Sixteenth Annual Report, Year ending September 30, 1942. Pp. 4. (London: Universities Federation for Animal Welfare.) [71 Medical Research Council: Nerve Injuries Committee. Aids to the Investigation of Peripheral Nerve Injuries. (M.R.C. War Memorandum No, 7.) Pp. 48. (London: H.M. Stationery Office.)
2s. net. 